\title{
Cooperative learning in higher education: differences in perceptions of contribution to the group
}

\author{
Francisco Jareño', Juan José Jiménez² \\ and M. Gabriela Lagos ${ }^{3}$ \\ 1. University of Castilla-La Mancha (UCLM), Spain | Francisco.Jareno@uclm.es \\ 2. University of Castilla-La Mancha (UCLM), Spain | Juan.Jimenez@uclm.es \\ 3. University of Castilla-La Mancha (UCLM), Spain | Gabriela.Lagos@uclm.es
}

Submitted in: September 2013

Accepted in: February 2014 Published in: May 2014

\section{Recommended citation}

Jareño, F., Jiménez, J.J. \& Lagos, M.G. (2014). Cooperative learning in higher education: differences in perceptions of contribution to the group. RUSC. Universities and Knowledge Society Journal, 11(2). pp. 66-80. doi http://dx.doi.org/10.7238/rusc.v11i2.1936

\begin{abstract}
This document analyses cooperative learning in a working group using a problem-based learning methodology. We also evaluate if the perception that each member of the group has of his/her contribution to cooperative learning is greater or lesser than that observed by his/her team-mates. Different elements of the work carried out in the group are analysed, such as the effective effort made, their participation, the organisation of the group, cohesion, communication, and the overall perception of their involvement in the cooperative learning and work. It is observed that the students perceive their contribution as greater than that perceived by their team-mates, although we find slight differences depending on the elements analysed.
\end{abstract}

\section{Keywords}

cooperative learning, interdisciplinary approach, problem-based learning (PBL), higher education

\section{Aprendizaje cooperativo en educación superior: diferencias en la percepción de la contribución al grupo}

\section{Resumen}

Este documento analiza el aprendizaje cooperativo en un grupo de trabajo en el que se utiliza metodología del aprendizaje basado en problemas. Además, se evalúa si la percepción que cada componente del grupo tiene de su aportación al aprendizaje cooperativo es mayor o menor que la percibida por sus compañeros. Se analizan diferentes aspectos del trabajo desarrollado dentro del grupo, como son el esfuerzo efectivo realizado, su participación, la organización del grupo, la cohesión, la comunicación y la percepción global de su implicación en el trabajo y el aprendizaje cooperativo. Se observa que los estudiantes perciben que su aportación es mayor que la percibida por sus compañeros, aunque encontramos ligeras diferencias en función de los aspectos analizados.

\section{Palabras clave}

aprendizaje cooperativo, interdisciplinariedad, aprendizaje basado en problemas (ABP), educación superior 


\section{Introduction}

Our objective is to study the cooperative learning developed in an activity that applies problem-based learning (PBL) with students of the Business Administration and Management degree at the Faculty of Economic and Business Sciences of Albacete, University of Castilla-La Mancha (UCLM), Spain.

PBL, applied to multidisciplinary activities, is an appropriate technique for reaching the objectives of competency development, such as individual responsibility, autonomous work, leadership, commitment to the group, etc.

Moreover, we analyse the perception that students have of the work carried out in the group in comparison to the perception that their team-mates have of their contribution to the group. The results obtained show that the perception of the students in relation to the contribution they make to the group is greater than that actually observed by the rest of the members of the group.

In our view, it is important to contrast the self-evaluation of the student with that received from the group in order to validate this teaching method in university practices. One of the constant complaints of the students in relation to group work is its impact on the final grade of the subject, since they consider this to be negative; that is, they tend to perceive their contribution, and thus, their grade, as higher than the actual one, in terms of peer evaluation.

The rest of this work is structured in the following way: in the second section, we look at the background of cooperative learning, the third section describes the case in hand, and in the fourth section the methodology used is explained. Finally, the results obtained are analysed in the fifth section and, in the sixth, the main conclusions are highlighted.

\section{Cooperative learning and problem-based learning methodology}

This article studies cooperative learning framed in an activity developed using a PBL methodology. This type of learning actively involves the student in the process, which allows for an increase in their motivation. It stimulates the student to argue his/her contributions in debates with the rest of the group members. PBL is based on the consideration of a problem prepared or selected by the teacher, the resolution of which will demand that the students acquire and develop certain previously defined competencies. In this methodology, the teacher adopts the role of facilitator and not transmitter of knowledge (Jiménez et al., 2013), which means a change in the classic paradigm of the teaching-learning process.

Arias-Gundín (2008) and Domingo (2008) highlight the importance of the renovation of certain teaching methodologies in the new context of higher education, although they also point to the difficulties that their application involves. One of these difficulties is found in the precise definition of cooperative work and collaborative work; thus, while the former involves stricter and more formal direction by the teacher, collaborative work allows for a greater degree of student autonomy. However, the advantage of cooperative learning warrants its application in this case, since some control of the students' activities is an objective we deem expedient. In any case, these active methodologies improve the achievement of competencies (Pujolàs i Maset, 2009), as they combine the acquisition of knowledge with the development of capabilities, attitudes, skills, etc.; these are necessary competencies for professional performance. But these authors warn of the limitations and difficulties of applying active methodologies, and they highlight the considerable effort demanded of the teachers, the necessary change of attitude in the students, the lack of work habits on the part of teachers and students in this type of methodologies, etc. 
Santillán and Siordía (2011) argue that this type of learning highlights the work carried out in the group, as well as the joint efforts between teachers and students, and they give special importance to the active and interactive participation of the students. Along similar lines, Jiménez et al. (2013) highlight the importance of this type of active work methodologies or learning strategies in order to develop professional competencies, like, for example, the capacity for effective communication and lifelong self-learning.

Much of the literature confirms the fact that students who work in cooperative groups have a greater sense of belonging to the group and become actively involved in the learning process, in contrast to what happens with other techniques or methodologies. In cooperative learning, the students must complete a task in which each individual should not only be concerned with his/her own learning, but also with that of the rest of his/her teammates.

According to Johnson and Johnson (1987), Lobato (1997), and Domingo (2008), for the work in a cooperative group to be effective, five basic components must be present: positive interdependence ("they are saved together or they drown together"), positive interaction (the members of the group encourage and support one another), individual demands or personal responsibility (with individual questions or tests), cooperative abilities (leadership, communication, conflict management, etc.) and, finally, self-analysis of the group's functioning (to correct possible malfunctions).

For Echeita (1995), Johnson and Johnson (1989), Slavin (1990), and León del Barco and Latas (2007), three basic requirements must be met in order to be able to speak of cooperative learning:

- the existence of a task that must be carried out in a group

- the resolution of that task or problem

- that the group's resources be sufficient to maintain and take forward its activity

This argument justifies the analysis developed in this research, given that a strategy of learning with cooperative groups fits perfectly with the adoption of a PBL methodology, according to the requirements described in the literature.

Indeed, Fernández et al. (2006) come to the conclusion that one of the elements most highly valued by the students that have followed a PBL approach is the cooperative work. Besides this, they also value the use of real problems and the creation of knowledge or, that is, of self-learning.

\section{Description of the problem-based learning activity}

The project presented in this article consists of an interdisciplinary activity across the areas of strategy, taxation, and finances, framed in a specialisation seminar for the bachelor's degrees in Business Administration and Management and in Economics at the Faculty of Economic and Business Sciences of Albacete, UCLM.

The main objective of the activity is to employ a PBL methodology incorporating three subjects of the degree in Business Administration and Management: strategic management, taxation systems, and financial management, such that the complementarity of the content and competencies allows business problems to be tackled in a comprehensive way. Furthermore, in this article we specifically analyse the perception that the students have in relation to their contribution to the work carried out in cooperative groups. 
Figure 1. View of the open virtual space on Moodle

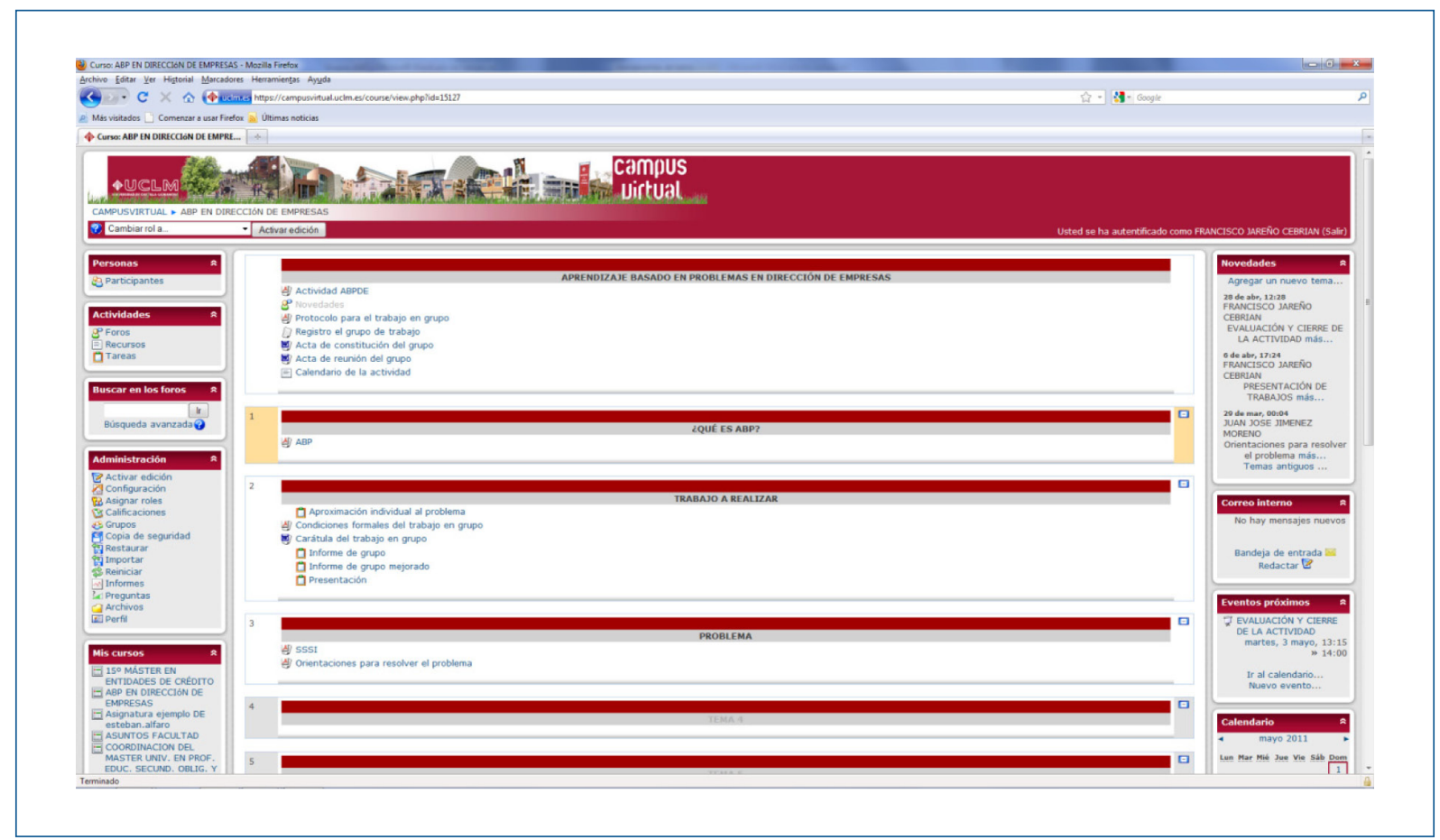

The activity is organised into two face-to-face sessions of two hours (one with presentations and another with project exposition and closing) and autonomous work (first individually and then in the group) lasting twenty hours, guided through face-to-face and/or virtual tutorials, with support from the seminar's virtual space located on Moodle (see Figure 1).

In the first face-to-face meeting, the teacher informs the students about PBL, presents the way of working in a PBL activity, and highlights the main roles that the members of the cooperative working groups must fulfil. Finally, the formal aspects are communicated to the students (protocols, make-up of the group, meeting minutes, etc.), as is the activity's timetable, in which the timing of the work to be carried out is explained. Furthermore, there are two phases to the project:

- A first phase of individual work, from which an approach for tackling or solving the problem emerges. Escribano and Jareño (2013) identify the tasks that the student should carry out in this first phase, which involves identifying the problems that appear in the situation considered, dealing with the learning involved, and the abilities, skills, and competencies necessary for reaching alternative resolutions that each student, individually, should propose.

- A second phase of group work, through cooperative learning. From this phase a second report emerges, which shows the proposed solution to the problem that the working group considers. Escribano and Jareño (2013) show that the members of each group will debate the problems to be resolved, with cooperative work, since all of the members of the group should participate and contribute value. Thus, all of the members of the group should be capable of defending any part of the project and are responsible for the solution contributed in its entirety.

Escribano and Jareño (2013, p. 83) defend the idea that: 
... the work methodology developed [... . highlights the importance of the students carrying out a first individual study and analysis of the problem, detecting and identifying what difficulties they find in the situation considered. On the individual level, each student should present a written report with an initial approach to the problem. In this way, the students will be able to take more from the second phase, which consists of group work (collaborative or cooperative). If the students have studied and evaluated previously and individually the problems of the situation considered, the group work will consist of sharing the individual analysis developed, as well as trying to find better solutions in a cooperative way.

Considering the work in two phases (one individual and another in-group) allows us to analyse what impact the group work has on the quality of the resolution of the problem. It is expected that such resolution will be considerably richer if the students take advantage of the group-work phase to cooperatively analyse all of the possible solutions and incorporate them into the final report.

With the conclusion of each phase, an evaluation of the work carried out is collected. This research focuses exclusively on analysing and evaluating the perception that each member has of the work carried out in the cooperative group, that is, the contribution of each student to the group work.

\section{Methodology used to analyse the differences in perceptions of work contributed to the group}

In order to analyse the perception that the students have of the work carried out in the group in comparison to the perception that the rest of the members have of their contribution to the group, different aspects of the group work are examined, such as effective work, participation, organisation of the group, cohesion, communication, and overall perception of their involvement in the cooperative work and learning.

To that end, we propose the use of a questionnaire evaluating the perception of the work of each member of the group (for the person in question as well as for the rest of the members). In accordance with the categories of evaluation proposed by Martín (2010), we therefore analyse qualitative variables (see Table 1).

This questionnaire shows the opinions of the students in relation to the indicators that gather information on these elements:

- Work: assessment of whether (or not) the student carries out the assigned tasks within the agreed time frame.

- Participation: analysis of the active participation of each student in the meetings and his/her sharing of information, knowledge, and experiences.

- Organisation: assessment of whether the student collaborates in the definition, organisation, and distribution of the group's tasks.

- Cohesion: assessment of whether the student gets involved in the achievement of the common agreements and objectives.

- Communication and interaction abilities: assessment of whether each student considers the points of view of the others and provides constructive feedback.

Each student evaluates these elements of the work carried out by each member of the group in the process of cooperative learning and of his/her own work, using a 5-point Likert scale, where 1 = not apt, 2 = needs improvement,

RUSC VOL. 11 No 2 Special Issue | Universitat Oberta de Catalunya and University of New England | Barcelona, May 2014

@. Francisco Jareño, Juan José Jiménez and M. Grabiela Lagos | @ FUOC, 2014 | Cooperative learning in higher education: differences in perceptions. 
Table 1. Extract of the evaluation questionnaire used to analyse perceptions of the work contributed in the process of cooperative learning

\begin{tabular}{|c|c|c|c|c|c|}
\hline INDICATORS & $\begin{array}{l}\text { NOT APT } \\
\text { (1) }\end{array}$ & $\begin{array}{c}\text { NEEDS } \\
\text { IMPROVEMENT (2) }\end{array}$ & $\begin{array}{l}\text { ADEQUATE } \\
\text { (3) }\end{array}$ & $\begin{array}{c}\text { GOOD } \\
(4)\end{array}$ & $\begin{array}{l}\text { EXCELLENT } \\
(5)\end{array}$ \\
\hline WORK & $\begin{array}{l}\text { Does not fulfil the } \\
\text { tasks assigned }\end{array}$ & $\begin{array}{l}\text { Partially fulfils the } \\
\text { tasks assigned or } \\
\text { is late }\end{array}$ & $\begin{array}{l}\text { Has the results of } \\
\text { the task assigned in } \\
\text { the established time } \\
\text { frame }\end{array}$ & $\begin{array}{l}\text { The quality of } \\
\text { the assigned task } \\
\text { represents a notable } \\
\text { contribution to the } \\
\text { team }\end{array}$ & $\begin{array}{l}\text { Fulfils the task } \\
\text { assigned and his/ } \\
\text { her work guides and } \\
\text { facilitates the work of } \\
\text { the rest of the group }\end{array}$ \\
\hline PARTICIPATION & $\begin{array}{l}\text { Often absent and } \\
\text { his/her presence is } \\
\text { irrelevant }\end{array}$ & $\begin{array}{l}\text { Intervenes very little } \\
\text { and almost always at } \\
\text { the request of others }\end{array}$ & $\begin{array}{l}\text { In general, he/ } \\
\text { she is active and } \\
\text { participative in the } \\
\text { group meetings }\end{array}$ & $\begin{array}{l}\text { Promotes } \\
\text { participation with } \\
\text { his/her interventions } \\
\text { and improves the } \\
\text { quality of the group's } \\
\text { result }\end{array}$ & $\begin{array}{l}\text { His/her contributions } \\
\text { are fundamental to } \\
\text { the process and the } \\
\text { quality of the result }\end{array}$ \\
\hline ORGANISATION & $\begin{array}{l}\text { Does not fulfil the } \\
\text { organisation and } \\
\text { distribution of the } \\
\text { tasks taken on }\end{array}$ & $\begin{array}{l}\text { Limits him/herself } \\
\text { to accepting the } \\
\text { organisation of the } \\
\text { work proposed by } \\
\text { others but fulfils it }\end{array}$ & $\begin{array}{l}\text { Participates in } \\
\text { the planning, } \\
\text { organisation, and } \\
\text { distribution of the } \\
\text { group work }\end{array}$ & $\begin{array}{l}\text { He/she is organised } \\
\text { and distributes the } \\
\text { work efficiently }\end{array}$ & $\begin{array}{l}\text { Boosts the } \\
\text { organisation of } \\
\text { the work taking } \\
\text { advantage of the } \\
\text { resources of the } \\
\text { group members }\end{array}$ \\
\hline COHESION & $\begin{array}{l}\text { Is guided by his/her } \\
\text { own objectives and } \\
\text { does not contribute } \\
\text { to those of the group }\end{array}$ & $\begin{array}{l}\text { Finds it difficult to } \\
\text { integrate his/her } \\
\text { personal objectives } \\
\text { with those of the } \\
\text { group }\end{array}$ & $\begin{array}{l}\text { Assumes the group } \\
\text { objectives as his/her } \\
\text { own }\end{array}$ & $\begin{array}{l}\text { Promotes the clear } \\
\text { definition of the } \\
\text { objectives and the } \\
\text { integration of the } \\
\text { group around them }\end{array}$ & $\begin{array}{l}\text { Mobilises and unites } \\
\text { the group towards } \\
\text { more demanding } \\
\text { objectives. Because of } \\
\text { this, the group stands } \\
\text { out for its performance } \\
\text { and quality }\end{array}$ \\
\hline $\begin{array}{l}\text { COMMUNICATION } \\
\text { AND INTERACTION } \\
\text { ABILITIES }\end{array}$ & $\begin{array}{l}\text { Does not listen } \\
\text { to team-mates' } \\
\text { interventions, } \\
\text { systematically } \\
\text { disqualifies them } \\
\text { and imposes his/her } \\
\text { opinions }\end{array}$ & $\begin{array}{l}\text { Does not listen } \\
\text { much, does not ask } \\
\text { questions, is not } \\
\text { concerned with the } \\
\text { opinion of the others. } \\
\text { His/her interventions } \\
\text { are redundant and } \\
\text { undemanding }\end{array}$ & $\begin{array}{l}\text { Accepts the others' } \\
\text { opinions and knows } \\
\text { how to share his/ } \\
\text { her point of view } \\
\text { constructively }\end{array}$ & $\begin{array}{l}\text { Boosts constructive } \\
\text { dialogue and inspires } \\
\text { the participation } \\
\text { of the other group } \\
\text { members }\end{array}$ & $\begin{array}{l}\text { Integrates the } \\
\text { opinions of the } \\
\text { others into a } \\
\text { higher perspective, } \\
\text { maintaining a climate } \\
\text { of collaboration and } \\
\text { support }\end{array}$ \\
\hline
\end{tabular}

3 = adequate, 4 = good, and 5 = excellent. In the questionnaire, it is explained that each student "evaluator" should fill in the first column with his/her self-evaluation for the different indicators, and in the following columns he/she should evaluate the other members of the group and propose improvements.

In accordance with Amo and Jareño (2011), the data obtained from the aforementioned questionnaire is processed by creating a measure that allows us to analyse the perception that the team-mates have of the contribution of a student to the group, and if this differs from the perception or assessment that the evaluated student has of his/her own contribution.

We consider a variable called dif, which is defined as:

$$
\operatorname{dif}_{j}=\text { Ev.teammates }_{j}-\text { Selfevaluation }_{j}
$$

where $\mathrm{dif}_{j}$ is the variable that shows the difference between the evaluation given by the team-mates on the work contributed to the group for each person $j$ and his/her self-evaluation. 
To obtain a measure of the team-mates' evaluation, an equally weighted mean of the assessments that the team-mates award to the evaluated student is calculated:

$$
\text { Ev.teammates }_{j}=\frac{\sum_{i=1}^{k} \text { Ev.teammates }_{j}^{i}}{k}
$$

Here, the variable Ev.teammates i refers to the evaluation that the student $i$ of the group assigns to the student $j$ analysed.

Thus, if (2) is incorporated into (1), in the end we have the following definition of the variable dif:

$$
\operatorname{dif}_{j}=\frac{\sum_{i=1}^{k} \text { Ev.teammates }_{j}^{i}}{k}-\text { Selfevaluation }_{j}
$$

The interpretation of the value that this variable may take is:

- If dif $_{j}>0 \rightarrow$ DIF POSIT $\rightarrow$ The team-mates have a perception of the work contributed to the group by the student analysed that is greater than that perceived by the student him/herself.

- If dif $_{j}=0 \rightarrow$ DIF ZERO $\rightarrow$ The members of the working group perceive that the contribution of the student analysed to the group is exactly the same as what he/she assigns to him/herself.

- If dif $_{j}<0 \rightarrow$ DIF NEGAT $\rightarrow$ The team-mates evaluate the work contributed by the student analysed with a lower score than that assigned by the student to him/herself.

The distribution of the variable allows us to discover if the students feel valued or not in the group.

\section{Analysis of the results of differences in perceptions of work in cooperative groups}

We take a sample of 48 students, divided into working groups of between 3 and 5 people, who participated in the same specialisation seminar held in the academic years 2010/11 (39 students) and 2011/12 (9 students). We propose to undertake an analysis of the total sample and of the sub-samples for the two academic years, just in case there are different patterns of behaviour.

Firstly, the statistical principles of the variable proposed in the study (dif $)$ are shown, both for the total sample (Table 2, Panel A) and for the two sub-samples (Table 2, Panels B and C).

In Table 2, we find a pattern of behaviour that is repeated in the total sample and in the two sub-samples analysed, which can be summarised in the following results:

- Work indicator: the mean of the proposed variable $\left(\mathrm{dif}_{\mathrm{j}}\right)$ is positive, which means that the assessment that the students award the person analysed is greater than that perceived by the student him/herself.

- Participation, organisation, and overall assessment (total): the results obtained offer a mean of the variable dif $f_{j}$ that shows negative values in the three cases. Therefore, the students perceive that their contribution to the group is greater than that which the other team-mates award to their work in the process of cooperative learning.

- Cohesion indicator: shows a result that is very similar to the previous indicators, the values of the variable dif are negative for the total sample and for the first sub-sample (academic year 2010/11). However, the second sub-sample (academic year 2011-12) does not show any differences between individual self-evaluation and the evaluation made by the group. 
Table 2. Statistical principles of the variable dif, which represents the difference between the perception of the team-mates and that of the individual student of the work contributed by each student.

Panel A: Total sample (academic years 2010/11 and 2011/12)

\begin{tabular}{|l|c|c|c|c|c|c|}
\multicolumn{1}{l|}{} & WORK & PARTICIPATION & ORGANISATION & COHESION & COMMUNICATION & TOTAL \\
\hline Mean & 0.0059 & -0.0451 & -0.0219 & -0.0087 & -0.0177 & -0.0889 \\
\hline Median & 0.0000 & 0.0000 & 0.0000 & 0.0000 & 0.0000 & -0.0250 \\
\hline Maximum & 0.2500 & 0.2500 & 0.3000 & 0.3333 & 0.2500 & 1.2500 \\
\hline Minimum & -0.4000 & -0.3500 & -0.4000 & -0.4000 & -0.3000 & -1.5500 \\
\hline Standard deviation & 0.1255 & 0.1324 & 0.1483 & 0.1513 & 0.1188 & 0.5053 \\
\hline Skewness & -0.4638 & -0.5472 & 0.0002 & -0.5324 & -0.1192 & -0.7543 \\
\hline Kurtosis & 4.3674 & 3.0801 & 3.0232 & 3.5741 & 3.2883 & 4.7725 \\
\hline Jarque-Bera test & 5.4600 & 2.4086 & 0.0011 & 2.9266 & 0.2800 & 10.8353 \\
\hline Probability & 0.0652 & 0.2999 & 0.9995 & 0.2315 & 0.8694 & 0.0044 \\
\hline Observations & 48 & 48 & 48 & 48 & 48 & 48 \\
\hline
\end{tabular}

Panel B: Academic year 2010/11

\begin{tabular}{|l|c|c|c|c|c|c|}
\multicolumn{1}{l|}{} & WORK & PARTICIPATION & ORGANISATION & COHESION & COMMUNICATION & TOTAL \\
\hline Mean & 0.0051 & -0.0427 & -0.0162 & -0.0107 & -0.0231 & -0.0850 \\
\hline Median & 0.0000 & 0.0000 & 0.0000 & 0.0000 & 0.0000 & 0.0000 \\
\hline Maximum & 0.2000 & 0.1333 & 0.3000 & 0.2000 & 0.2500 & 0.6000 \\
\hline Minimum & -0.4000 & -0.3500 & -0.4000 & -0.4000 & -0.3000 & -1.5500 \\
\hline Standard deviation & 0.1095 & 0.1119 & 0.1376 & 0.1330 & 0.0986 & 0.4272 \\
\hline Skewness & -0.9642 & -1.1233 & -0.2375 & -1.1631 & -0.2826 & -1.5652 \\
\hline Kurtosis & 6.7078 & 4.0234 & 3.7854 & 4.8299 & 4.4623 & 6.2811 \\
\hline Jarque-Bera test & 28.3835 & 9.9030 & 1.3691 & 14.2352 & 3.9940 & 33.4195 \\
\hline Probability & 0.0000 & 0.0071 & 0.5043 & 0.0008 & 0.1357 & 0.0000 \\
\hline Observations & 39 & 39 & 39 & 39 & 39 & 39 \\
\hline
\end{tabular}

Panel C: Academic year 2011/12

\begin{tabular}{|l|c|c|c|c|c|c|}
\multicolumn{1}{l|}{} & WORK & PARTICIPATION & ORGANISATION & COHESION & COMMUNICATION & TOTAL \\
\hline Mean & 0.0093 & -0.0556 & -0.0463 & 0.0000 & 0.0056 & -0.1056 \\
\hline Median & 0.0000 & -0.0833 & -0.0833 & 0.0000 & 0.0000 & -0.0833 \\
\hline Maximum & 0.2500 & 0.2500 & 0.2500 & 0.3333 & 0.2500 & 1.2500 \\
\hline Minimum & -0.2500 & -0.3333 & -0.2500 & -0.2500 & -0.2500 & -1.2500 \\
\hline Standard deviation & 0.1884 & 0.2083 & 0.1959 & 0.2244 & 0.1898 & 0.7953 \\
\hline Skewness & 0.0615 & 0.1075 & 0.5942 & 0.1223 & -0.2603 & 0.0596 \\
\hline Kurtosis & 1.5481 & 1.5576 & 1.8670 & 1.5999 & 1.5800 & 2.3354 \\
\hline Jarque-Bera test & 0.7962 & 0.7975 & 1.0110 & 0.7575 & 0.8578 & 0.1710 \\
\hline Probability & 0.6716 & 0.6712 & 0.6032 & 0.6847 & 0.6512 & 0.9181 \\
\hline Observations & 9 & 9 & 9 & 9 & 9 & 9 \\
\hline
\end{tabular}


- Communication indicator: offers results that also vary between the total sample and the first sub-sample and the second sub-sample. The dif j $_{\text {mean }}$ is negative in the first case (the students value themselves above the grade assigned by the rest of the group members), whereas the value becomes slightly positive in the second case (each student evaluates him/herself exactly the same as his/her team-mates do)?.

In order to confirm these results we can compare if the mean values studied are significantly different from zero or not, to be able to conclude if, indeed, the assessments awarded by the team-mates to the student analysed are different to those that the student assigns to him/herself.

The results are shown in Table 3:

Table 3. Comparison confirming if the mean of the variable dif is significantly different from zero

\begin{tabular}{|l|c|c|c|c|c|c|}
\multicolumn{1}{l|}{} & WORK & PARTICIPATION & ORGANISATION & COHESION & COMMUNICATION & TOTAL \\
\hline TOTAL & 0.0059 & $-0.0451^{\mathrm{a}}$ & -0.0219 & -0.0087 & -0.0177 & -0.0889 \\
\hline SUB-1 & 0.0051 & $-0.0427^{\mathrm{a}}$ & -0.0162 & -0.0107 & -0.0231 & -0.0850 \\
\hline SUB-2 & 0.0093 & -0.0556 & -0.0463 & 0.0000 & 0.0056 & -0.1056 \\
\hline
\end{tabular}

${ }^{a} \mathrm{p}<0.05$

The comparisons carried out confirm that the most important differences are in the participation indicator. The students perceive their involvement in the work carried out during the process of cooperative learning as much greater than that contributed by the rest of the team-mates. This confirms the general belief that most of the students have, which is that, in group work, it is perceived that the work carried out individually may be being taken advantage of by the group's so-called "parasites". These students contribute "little" to the group, but they obtain the same reward as the rest of the team-mates (unless these malfunctions are intercepted by the team-mates and/or by the teacher).

The results obtained are shown graphically in Figure 2, distinguishing between the total sample (Panel A) and the two sub-samples (Panels B and C).

1. The results of the second sub-sample must be taken cautiously, due to the small number of questionnaires. 
Figure 2. Percentage distribution of the differences between the perception of the group members and that of the student in relation to his/her contribution to the group

\section{Panel A: Total sample (academic years 2010/11 and 2011/12)}

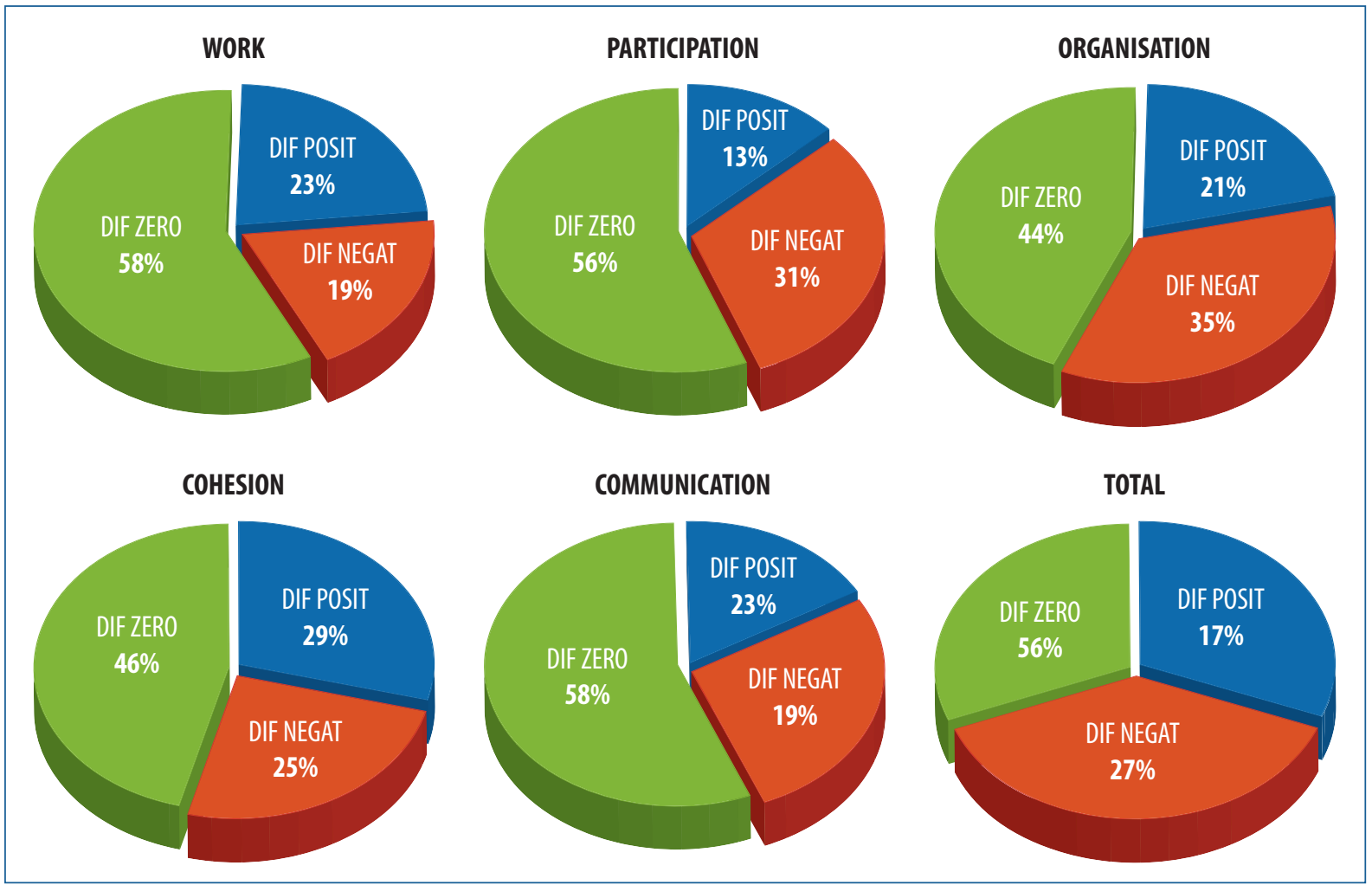

\section{Panel B: Academic year 2010/11}

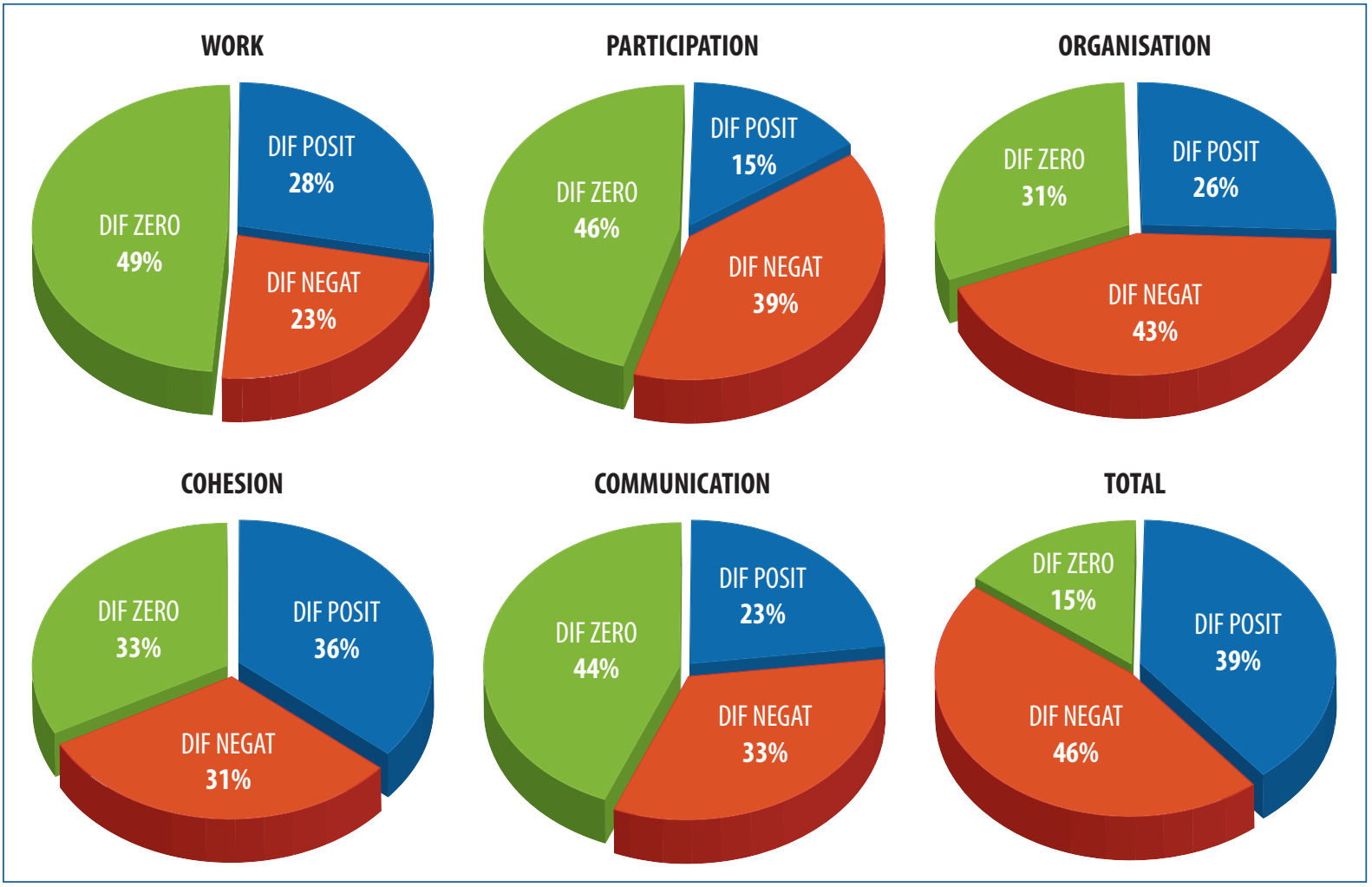

RUSC VOL. 11 No 2 Special Issue | Universitat Oberta de Catalunya and University of New England | Barcelona, May 2014

@. Francisco Jareño, Juan José Jiménez and M. Grabiela Lagos | @ FUOC, 2014 | Cooperative learning in higher education: differences in perceptions... 


\section{Panel C: Academic year 2011/12}

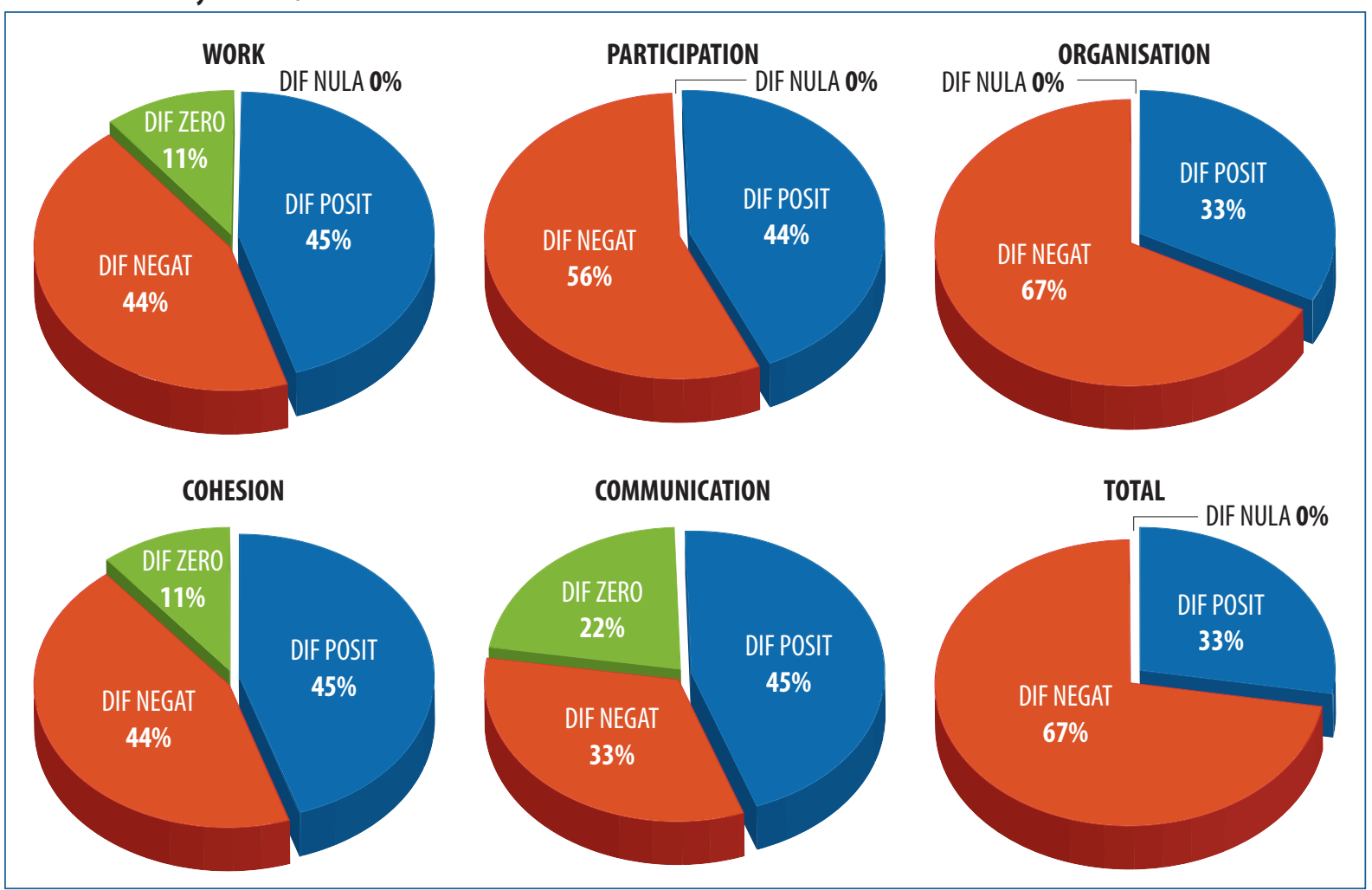

Since the fundamental objective of this work consists in analysing if (significant) differences exist between the student's perception of work contributed to the group and the perception his/her team-mates have of said contribution, we exclude those zero differences found, when both evaluations coincide. Thus, Figure 3 reproduces the information shown in Figure 2, but eliminating DIF ZERO (dif $=0)$.

Regarding the differences, both of the total sample and of the sub-samples:

- In relation to participation, organisation, and total (overall assessment), similar results are found in the total sample and in the two sub-samples, which can be summarised in higher percentages of DIF NEGAT than those found for DIF POSIT. According to this, the students perceive that their involvement in the participation, organisation and, in general, in the work undertaken in the process of cooperative learning in the group has been higher than that assessed by the rest of the students in the group.

- On analysing the communication indicator, we observe a different pattern of behaviour between, on the one hand, the total sample and the first sub-sample (Panels A and B), and on the other hand, the sub-sample corresponding to academic year 2011/12 (Panel C). In the first case, the measure identified as DIF NEGAT offers higher percentages than that of DIF POSIT, which means that the students perceive a greater individual contribution to the group than that perceived by the group itself. However, the second sub-sample shows the opposite result; here, it is the variable DIF POSIT which offers a higher percentage (57\%).

- Finally, in relation to work and cohesion, the total sample and the 2010/2011 sample show some differences between the percentages found in the measure DIF POSIT (approximately 45\%) and DIF NEGAT (approximately 55\%). However, the sub-sample from academic year 2011/12 (Panel C) offers the same percentage for both measures. 
Figure 3. Percentage distribution of the differences between the perception of the group members and that of the student in relation to his/her contribution to the group

\section{Panel A: Total sample (academic years 2010/11 and 2011/12)}

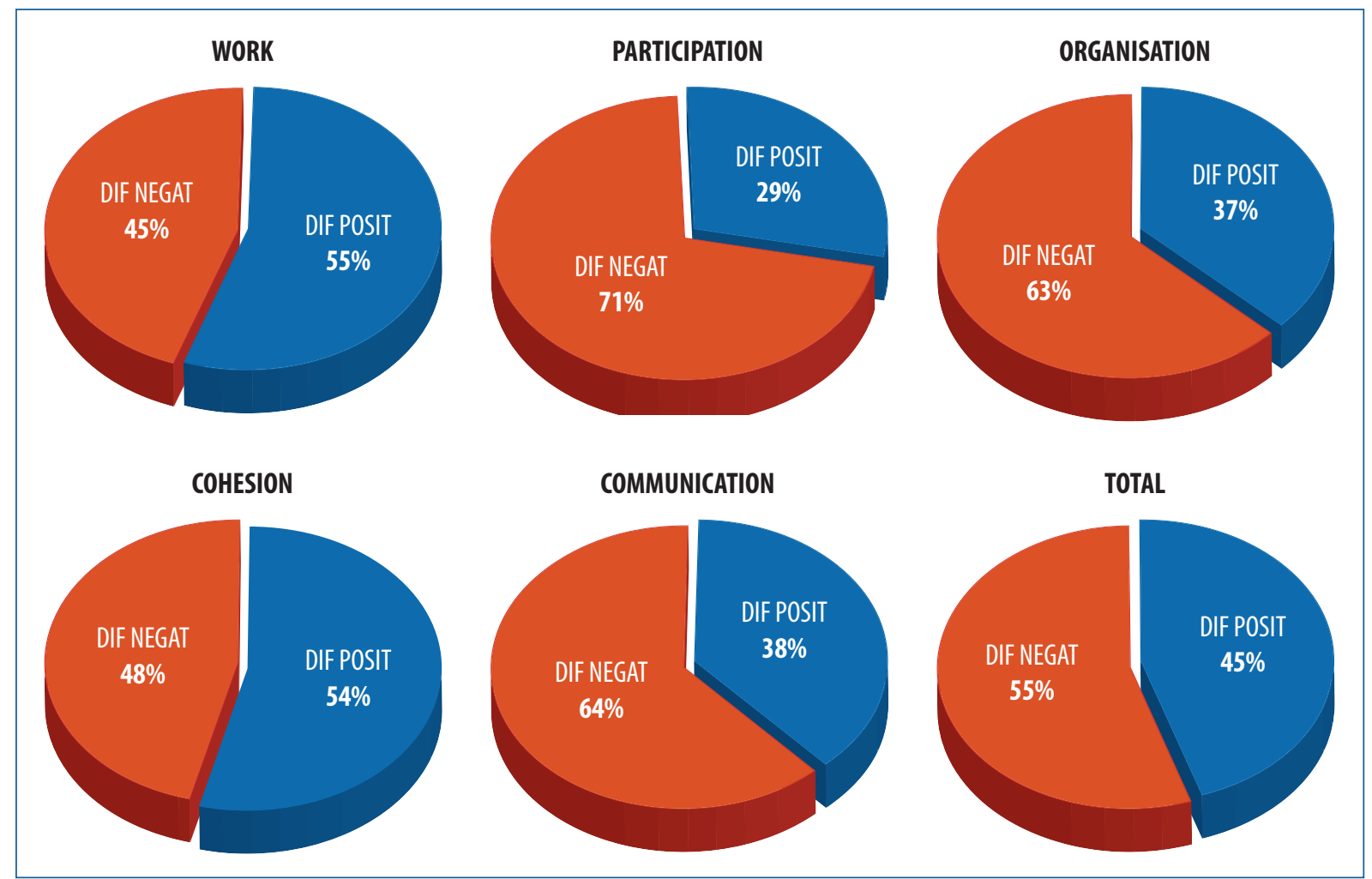

\section{Panel B: Academic year 2010/11}

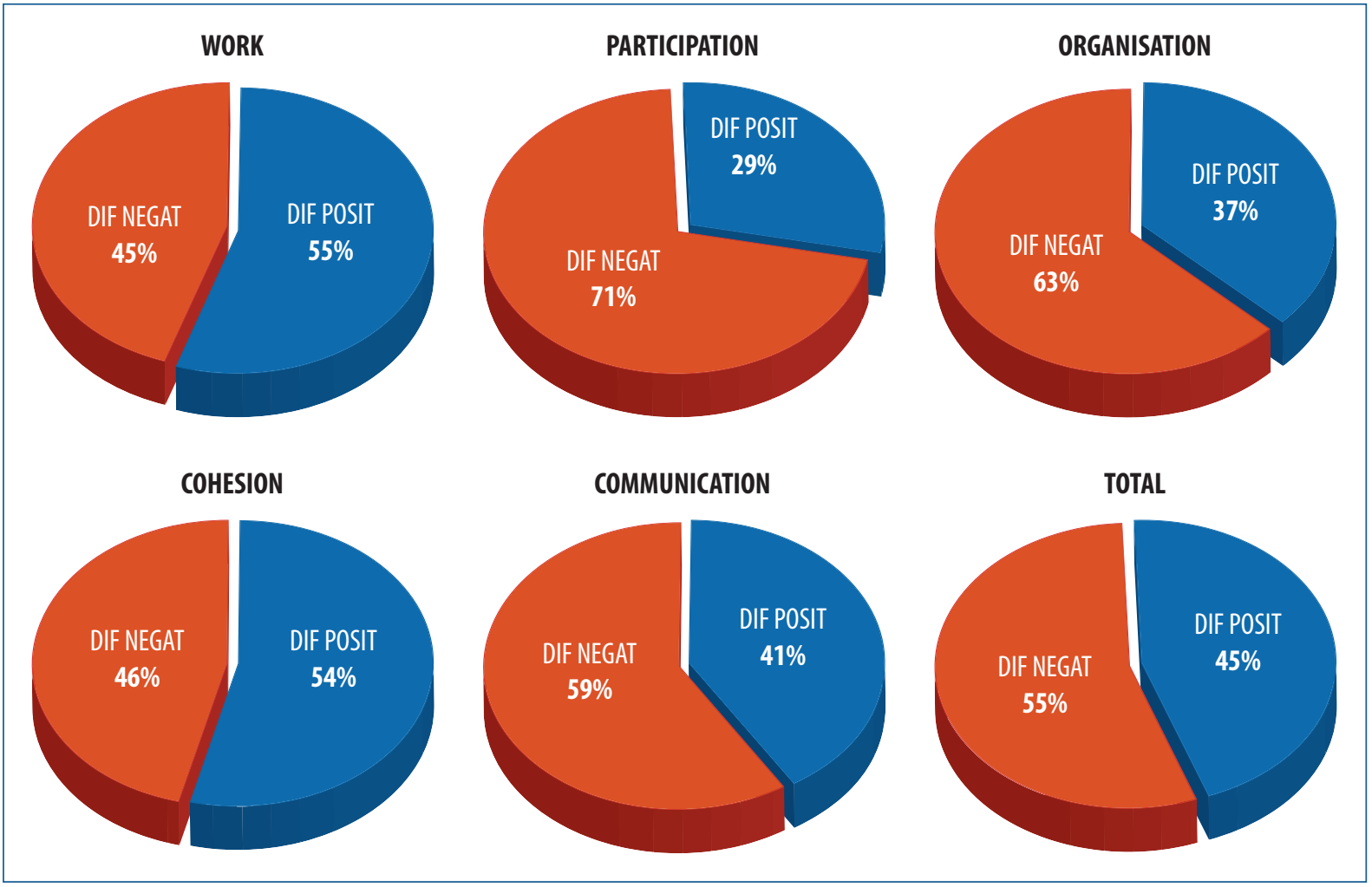

RUSC VOL. 11 No 2 Special Issue | Universitat Oberta de Catalunya and University of New England | Barcelona, May 2014

@a Francisco Jareño, Juan José Jiménez and M. Grabiela Lagos | @ FUOC, 2014 | Cooperative learning in higher education: differences in perceptions. 


\section{Panel C: Academic year 2011/12}

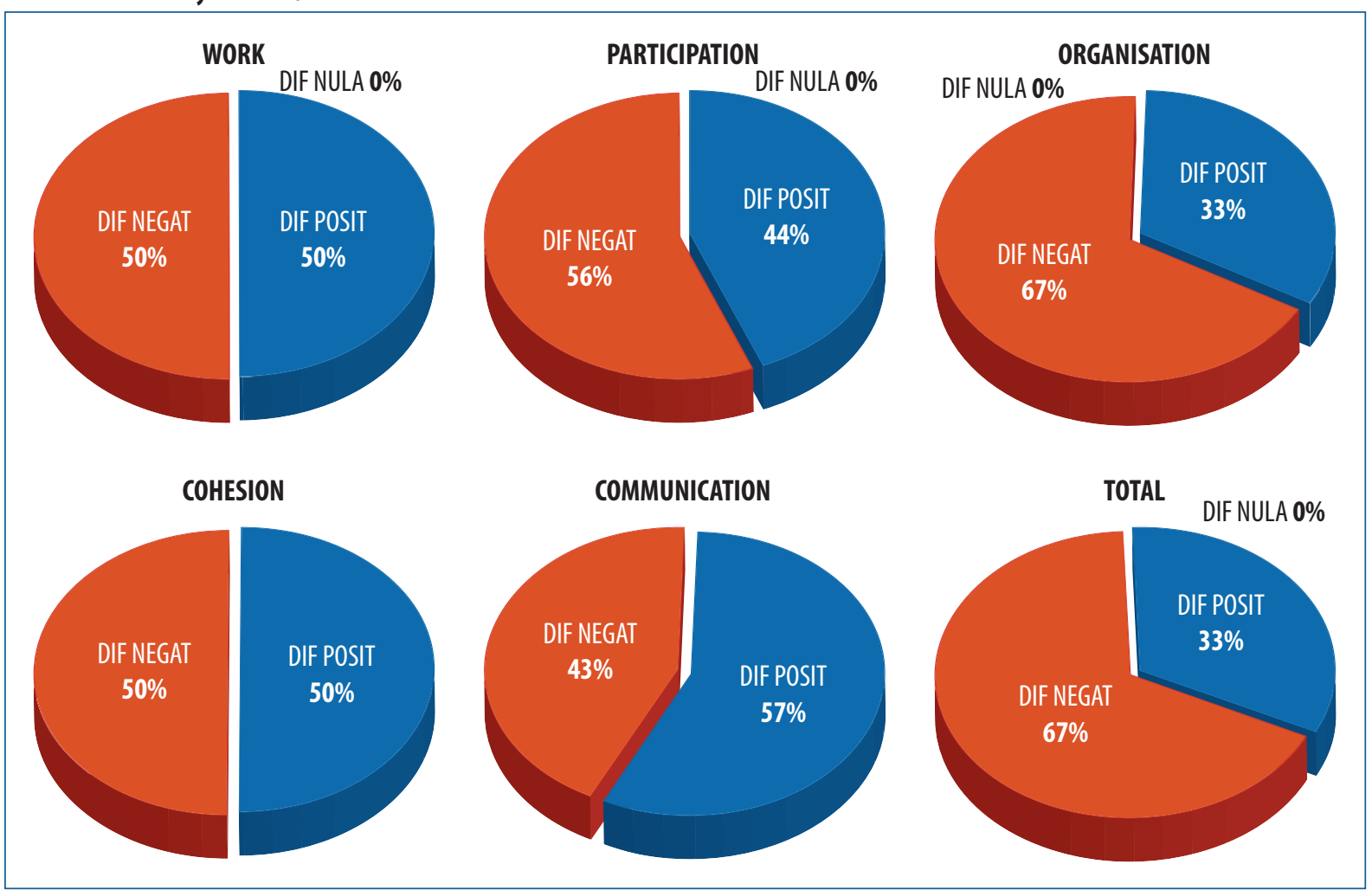

\section{Conclusions}

The new bachelor's degrees have entailed a change of model that involves the introduction of new instruments for the evaluation of competency acquisition. One of the most commonly fostered cross-disciplinary competencies is group work (capacity for teamwork, leading, directing, planning, and supervising multidisciplinary and multicultural teams). It is therefore relevant to find out the opinion of the students on the suitability of the evaluation instrument and the fairness of the result.

In this paper, we have applied a measure of evaluation that allows us to analyse the members' perception of their own contribution to cooperative learning in relation to that perceived by their team-mates, analysing different elements:theeffectiveworkcarried out, theirparticipation, theorganisation within the group,cohesion,communication, and overall perception of their involvement in the cooperative work and learning (total or overall assessment).

The results obtained allow us to assert that the students perceive that their contribution to the group work is greater than that observed by their team-mates, although slight differences are found depending on the elements analysed. This perception is much more striking when we analyse the total sample and, fundamentally, when we study the indicators of participation, organisation, communication, and overall assessment (total).

Consequently, these results would lead us to revise the weight of group work in the final grade of the student. Nevertheless, the reduction of its weight does not resolve the problem of the acceptance of the method by the students; hence, we consider that the essential issue is to consider improving the process of cooperative work, aiming for the convergence of the self-evaluations and those made by the group. The key, in our view, is to introduce 
mechanisms that give more visibility to the individual contribution, with improvements in the follow-up of the meeting minutes, for example.

\section{References}

Amo, E., \& Jareño, F. (2011). Self, peer and teacher assessment as active learning methods. Research Journal of International Studies, 18, 41-47. Retrieved from http://www.eurojournals.com/RJIS_18_05.pdf

Arias-Gundín, O., Fidalgo, R., \& García, J. N. (2008). El desarrollo de las competencias transversales en Magisterio mediante el aprendizaje basado en problemas y el método del caso. Revista de Investigación Educativa, 26(2), 431-444. Retrieved from http://revistas.um.es/rie/article/view/94011/90631

Domingo, J. (2008). El aprendizaje cooperativo. Cuadernos de Trabajo Social, 21, 231-246. Retrieved from http:// revistas.ucm.es/index.php/CUTS/article/view/CUTS0808110231A/7531

Echeita, G. (1995). El aprendizaje cooperativo. Un análisis psicosocial de sus ventajas respecto a otras estructuras de aprendizaje. In P. Fernández \& A. Melero (Eds.). La interacción social en contextos educativos (pp. 175-190). Madrid: Siglo XXI.

Escribano, F., \& Jareño, F. (2013). Aplicación de la metodología ABP en el Máster Universitario en Consultoría y Asesoría Financiera y Fiscal. In E. Farinós \& A. Escribano (Eds.). Experiencias de innovación educativa en finanzas (pp. 73-87). Valencia: Tirant Lo Blanch.

Fernández, M., García, J. N., De Caso, A., Fidalgo, R., \& Arias, O. (2006). El aprendizaje basado en problemas. Revisión de estudios empíricos internacionales. Revista de Educación, 341, 397-418. Retrieved from http://www. revistaeducacion.mec.es/re341/re341_17.pdf

Jiménez, J. J., Lagos, M. G., \& Jareño, F. (2013). El Aprendizaje Basado en Problemas como instrumento potenciador de las competencias transversales. E-pública. Revista electrónica sobre la enseñanza de la Economía Pública, 13, 44-68. Johnson, D. W., \& Johnson, R. (1987). Learning together and alone. Englewood Cliffs, NJ: Prentice Hall.

Johnson, D. W., \& Johnson, R. (1989). Cooperation and competition. Edina, MN: Interaction Book Company.

León del Barco, B., \& Latas Pérez, C. (2007). La formación en técnicas de aprendizaje cooperativo del profesor universitario en el contexto de la convergencia europea. Revista de Psicodidáctica, 12(2), 269-278. Retrieved from http://www.ehu.es/ojs/index.php/psicodidactica/article/view/224/220

Lobato, C. (1997). Hacia una comprensión del aprendizaje cooperativo. Revista de Psicodidáctica, 4, 59-76. Retrieved from http://www.ehu.es/ojs/index.php/psicodidactica/article/view/58/58

Martín, T. (2010). Autoevaluación grupal del proceso de aprendizaje e informe de los resultados. Plan de Acogida y Formación de los Estudiantes de 1. de Grado. Retrieved from http://www.uclm.es/organos/vic_ ordenacionacademica/uie/plan_acogida_formacion.htm

Pujolàs i Maset, P. (2009). La calidad en los equipos de aprendizaje cooperativo. Algunas consideraciones para el cálculo del grado de cooperatividad. Revista de Educación, 349, 225-239. Retrieved from http://www. revistaeducacion.mec.es/re349/re349.pdf

Santillán, F., \& Siordía, S. (2011). El aprendizaje basado en problemas como propuesta educativa para las disciplinas económicas y sociales apoyadas en el B-learning. Revista Iberoamericana para la Investigación y el Desarrollo Educativo, 7, 1-28. Retrieved from http://www.ride.org.mx/docs/publicaciones/07/07-072011.pdf

Slavin, R. E. (1990). Cooperative learning. Theory, research and practice. Englewood Cliffs, NJ: Prentice Hall. 


\section{About the authors}

Francisco Jareño

Francisco.Jareno@uclm.es

Department of Economic Analysis and Finance, Faculty of Economic and Business

Sciences, University of Castilla-La Mancha (UCLM), Spain

Francisco Jareño is a university lecturer and carries out his research in the area of Finance, specifically in the study of the term structure of interest rates and volatilities. Moreover, he participates in several teaching and educational research innovation projects on evaluation techniques and teaching methodologies.

\section{Juan José Jiménez}

Juan.Jimenez@uclm.es

Department of Business Management, University of Castilla-La Mancha (UCLM), Spain

Juan J. Jiménez is a senior lecturer in the area of Business Organisation, and his line of research focuses on entrepreneurship, business results, and entrepreneurial training, as well as the transfer of new teaching methodology.

\section{Gabriela Lagos}

Gabriela.Lagos@uclm.es

Department of Political Economy and Public Finance, Economic and Business

Statistics and Economic Policy, University of Castilla-La Mancha (UCLM), Spain

M. Gabriela Lagos is a university lecturer and specialist in business taxation. She participates in several projects on the impact of taxation on the creation of companies, as well as others dealing with problem-based learning (PBL) as a teaching method.

University of Castilla-La Mancha

Plaza de la Universidad, 1

02071 Albacete

Spain

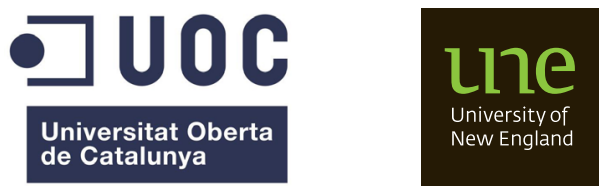

